\title{
Eighty Years of Cooperative Water Science
}

\section{Why was the Equus Beds Aquifer Storage and Recovery (ASR) Project needed?}

- The Equus Beds ASR project is a recent part of an 80 -year cooperative water science effort with the city of Wichita, Kansas.

- The aquifer can provide up to 60 percent of Wichita's water supply. Access to water stored by ASR is essential to meet needs during a 1-percent drought.

- Aquifer water levels substantially decreased by 1993 because historical pumping during drought was greater than natural recharge.

- Saltwater contamination from the Arkansas River and previous oil and gas activity near Burrton, Kansas, is moving toward the wells.

- Water for ASR is captured from the Little Arkansas River, treated, and recharged to the aquifer through infiltration basins and injections for later use.

"We depend on unbiased USGS science to define progress of recharge, develop new tools for management, and understand the water quality of the aquifer. These are all critical to the longevity of our water supply." - Scott Macey, Water Resources Engineer, city of Wichita

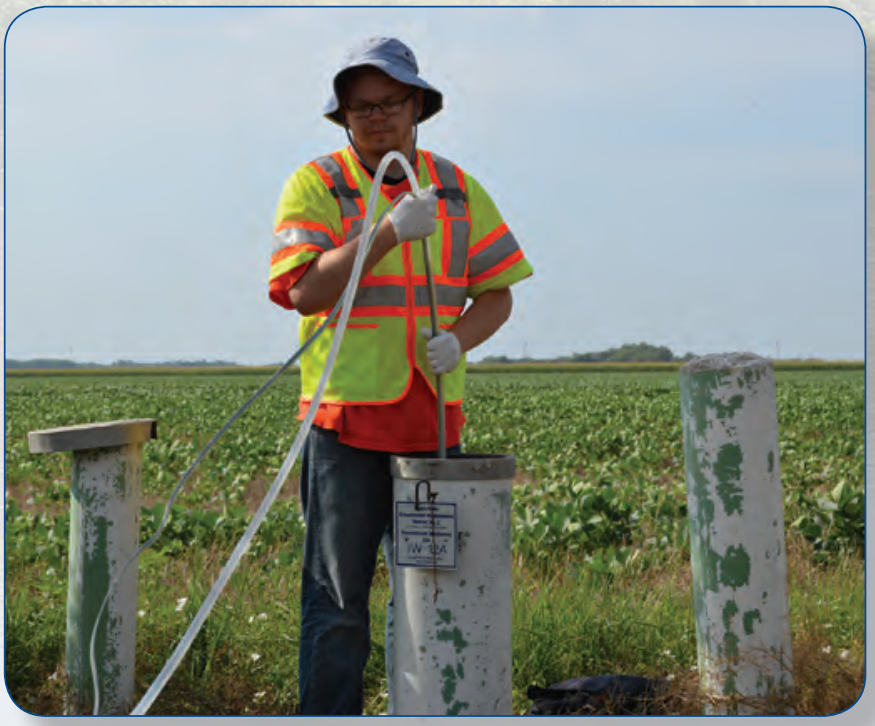

Groundwater sampling in the Equus Beds aquifer, Kansas

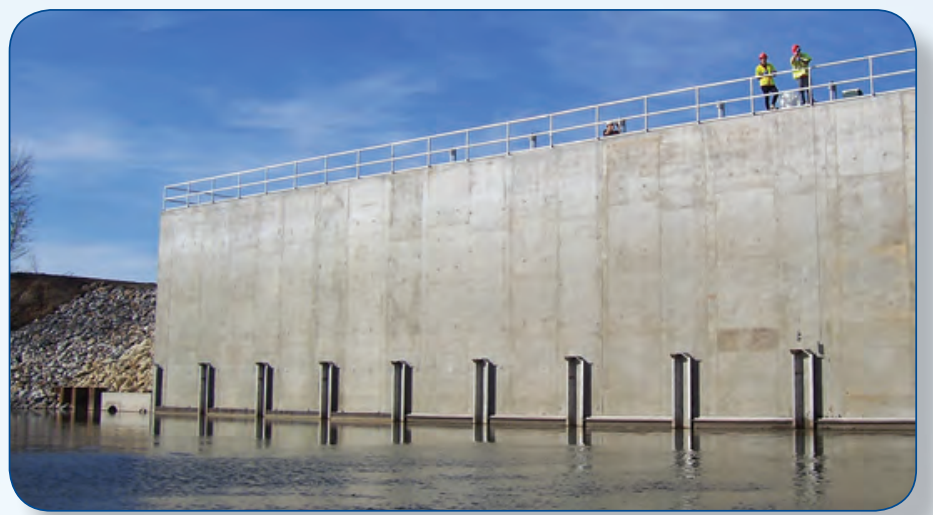

Aquifer Storage and Recovery Phase II intake structure along the Little Arkansas River, Kansas

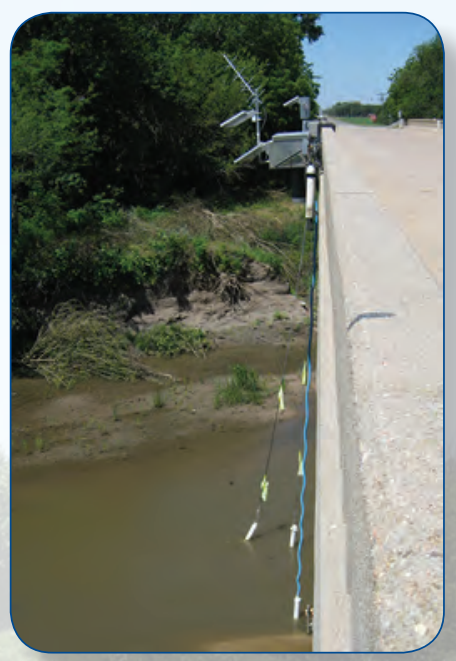

Water-quality monitors in the Little Arkansas River, Kansas

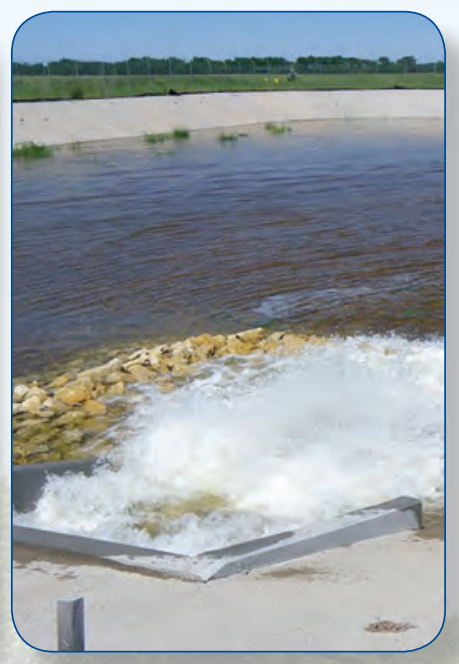

Recharge basin near Sedgwick, Kansas

\section{History of Wichita Water-Supply Development and USGS/City of Wichita Cooperatively Funded Studies}

1920s: Local well field developed and USGS streamgage installed.

1930-50s: USGS water-level monitoring and city of Wichita well field developed.

1960-80s: Cheney Reservoir constructed; Groundwater Management District 2 formed; Burrton Intensive Groundwater Use Control Area established.

1990s-2019+: The 1990s and 2011-13 drought emphasized aquifer replenishment need; USGS waterquality monitoring and interpretation for Demonstration Project (1995-2002); Phase I (2007); Phase II (2013-2019+); new USGS groundwater model constructed (2014). 


\section{Role of USGS Science in Managed Aquifer Recharge}

To provide data and interpretation for unbiased, objective water-quantity and quality information to establish a scientific foundation for water-management decisions.
To develop innovative tools that can be used throughout the United States with applications ranging from realtime data for operations to long-term modeling for projections and resource management.
The USGS Kansas Water Science Center characterizes river and aquifer water-quality and quantity and evaluates changes that may or may not be related to ASR.

The USGS data are used by the city of Wichita to make informed management decisions, satisfy regulatory requirements, and serve as a baseline to detect any subsequent changes that may be related to ASR.

The amount of aquifer water volume stored increased between the historic 1993 low and 2016. Increases are from less pumping, more natural recharge, and ASR.

A chloride plume (orange area on map) moves about 0.6 feet per day toward the decline in water levels caused by overpumping (purple area on map). Contamination of the city of Wichita's water-supply wells is inevitable unless actions are taken to remove the chloride. ASR can slow or dilute the chloride plume.

The city of Wichita has recharged about 4,560 million gallons (14,000 acre-feet) to the aquifer during 2007 through July 2019.

Water-quality contaminants are from natural and human sources. Artificial recharge is not contributing to groundwater contamination.

Aquatic macroinvertebrates are collected for bioassessment of ASR potential effects on the Little River.

Surface water-quality constituent concentrations are controlled by hydrology rather than effects of ASR activities.

Continuously measured water quality is an effective management tool to measure changes and trends.

The Equus Beds study is funded in part by USGS cooperative matching funds and the city of Wichita.

Many Federal, State, and local agencies and consultants contributed funds and expertise to ensure the sustainability of this important regional water resource.

For more information on the city of Wichita ASR Program: https://wichitaasr.org/

USGS Equus Beds ASR study: https://www.usgs.gov/ centers/kswsc/science-topics/equus-beds-aquifer

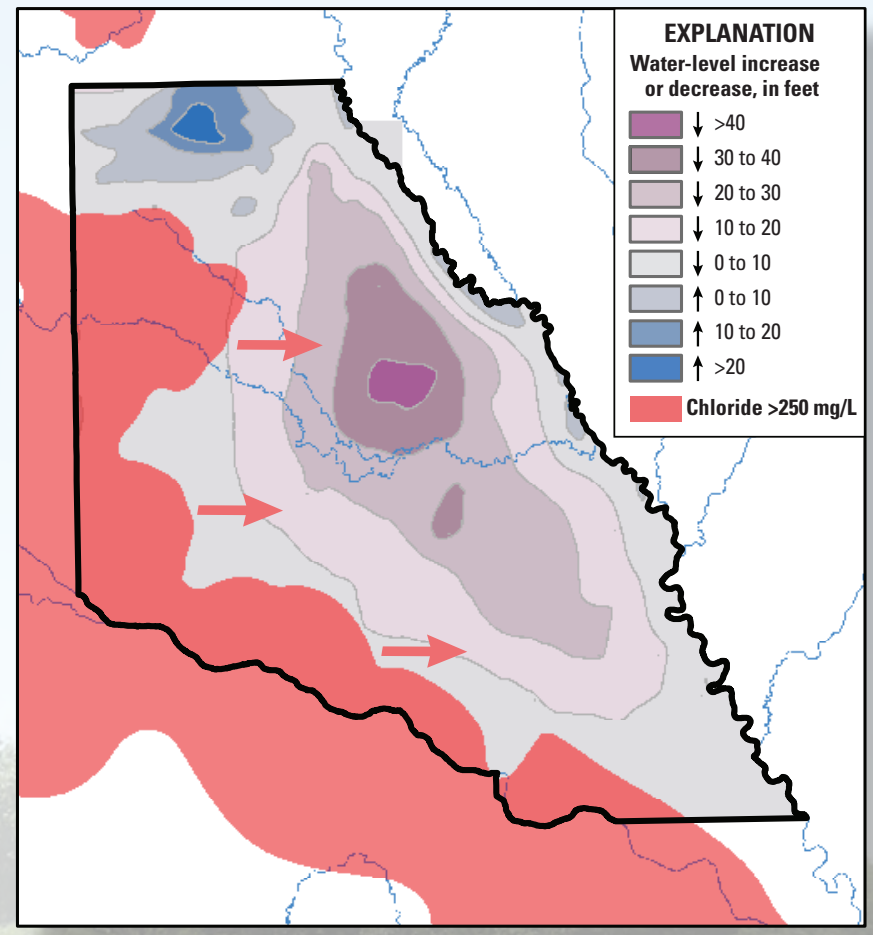

Equus Beds shallow water-level changes, predevelopment to 1993, and deep wells with chloride exceeding 250 milligrams per liter, 2006-12.

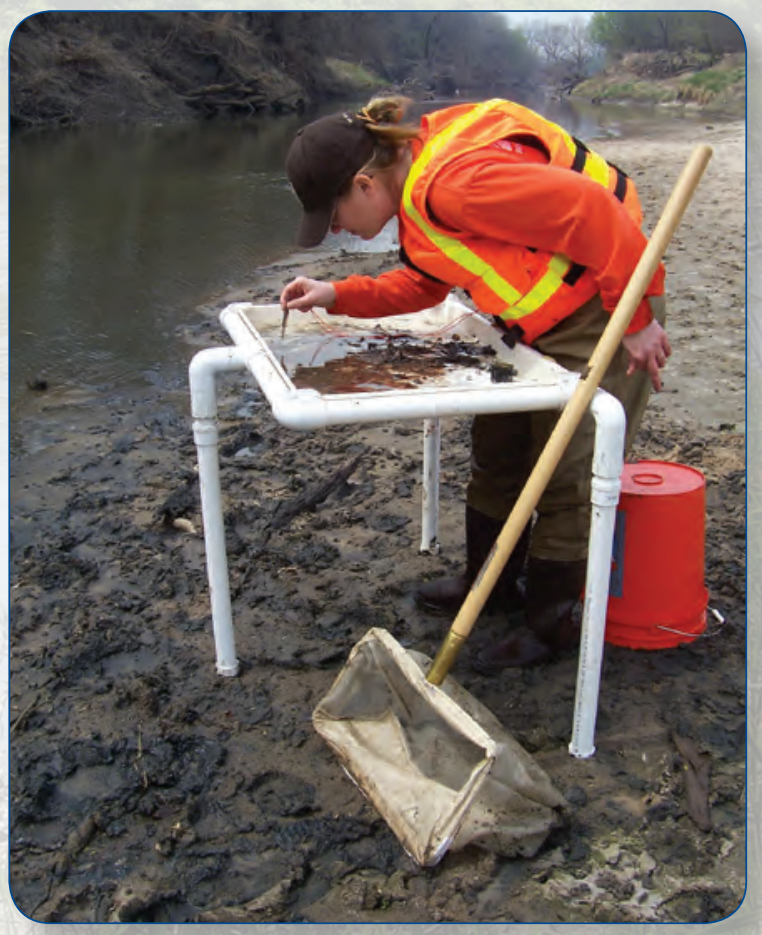

Macroinvertebrate sampling along the Little Arkansas River, Kansas 